Original Research Paper

\title{
Determining the Eutrophication State of Ecbatan Reservoir using Carlson Index
}

\author{
${ }^{1}$ Maryam Ghashghaie, ${ }^{2}$ Mohammad Reza Serajian Maralan, \\ ${ }^{3}$ Kaveh Ostad-Ali-Askari, ${ }^{4}$ Saeid Eslamian and ${ }^{5}$ Vijay P. Singh \\ ${ }^{I}$ Department of Water Resources Engineering, Faculty of Agriculture, Bu-Ali Sina University, Hamedan, 6517833131, Iran \\ ${ }^{2}$ Department of Surveying and Geomatics Engineering, University of Tehran, Tehran, Iran \\ ${ }^{3}$ Department of Civil Engineering, Isfahan (Khorasgan) Branch, Islamic Azad University, Isfahan, Iran \\ ${ }^{4}$ Department of Water Engineering, Isfahan University of Technology, Isfahan, Iran \\ ${ }^{5}$ Department of Biological and Agricultural Engineering and Zachry Department of Civil Engineering, \\ Texas A and M University, 321 Scoates Hall, 2117 TAMU, College Station, Texas 77843-2117, U.S.A
}

\author{
Article history \\ Received: 18-02-2018 \\ Revised: 02-04-2018 \\ Accepted: 18-04-2018 \\ Corresponding Author: \\ Kaveh Ostad-Ali-Askari \\ Department of Civil \\ Engineering, Isfahan \\ (Khorasgan) Branch, Islamic \\ Azad University, Isfahan, Iran. \\ Email: koa.askari@khuisf.ac.ir
}

\begin{abstract}
Reservoirs are vital and necessary resources of potable water. Different sectors such as agriculture, industry and fishery are dependent on these resources which need high quality water. Water quality is mainly evaluated using different parameters such as $\mathrm{pH}$, temperature and turbidity which are easily measured. Also there are some more complicated parameters such as eutrophication degree of a water body. This study was accomplished to investigate the trophic state of Ecbatan reservoir in dry and wet seasons. Water sampling was accomplished in July and January to compare the trophic state of the reservoir in two critical situation of a hydrologic dry year. 15 stations were selected in different points of the reservoir. Different parameters of water quality were measured such as temperature, $\mathrm{pH}$, Secchi Disk (SD), Total Nitrate (TN), Total Phosphate (TP) and chlorophyll-a (chla). The trophic state was estimated for all stations using Carlson index. Results of the study show that trophic state of the lake is mild mesotrophic in July and acute mesotrophic in January. Also Phosphorous is the limiting nutrient in this reservoir. This research showed that eutrophication is a serious problem in Ecbatan reservoir and managerial strategies are required to prevent water quality deterioration.
\end{abstract}

Keywords: Carlson Index, Dry Year, Ecbatan Reservoir, Eutrophication, Trophic State Index (TSI), Water Quality

\section{Introduction}

Iran is a dry country located in the Middle East. Fresh water resources are very important for surrounding environment and society in this country. Many reservoirs have been built to supply clean and healthy water. These resources are used to supply potable water for urban and rural areas, industry, agriculture and recreation purposes. All of these sectors need a healthy resource of water.

Natural and artificial lakes such as reservoirs are exposed to more pollution as a result of their geometry and characteristics of water bodies. Nutrients have more opportunity to settle and remain in these systems. Consequently the possibility of eutrophication phenomenon is higher in such ecosystems. Many studies have been accomplished on the eutrophication of reservoirs. These studies are mainly accomplished to investigate the quality of water in reservoirs and could ultimately lead to practical solutions to protect the quality of these resources.

Any increase in eutrophication rate increases the biomass of algae in water bodies such as rivers, ponds, coastal areas and reservoirs (Camargo et al., 2005; Kurz et al., 2005). Nitrogen (N) and Phosphorus (P) are main nutrients which affect the growth of algae and increase the amount of chla directly (Smith, 2003). Based on the ratio of eutrophication in a water body $\mathrm{N}$ or $\mathrm{P}$ could be the limiting factor. Li et al. (2015) determined the limiting nutrient in Yuqiao reservoir and controlled the amount of nutrient entrance to a threshold that prevented eutrophication. $\mathrm{P}$ was identified as the limiting factor in this reservoir. 
Eutrophication limits the application and consumption of water, since algae clog filtration equipment and suction pipes in refineries, change the taste and odor of water and cause some disease (Domagalski et al., 2007; Smith et al., 2005). Excessive growth of algae and water plants reduces the amount of Dissolved Oxygen (DO) (Zhang et al., 2007; Arheimer et al., 2004). As a result fishes will die and biological species will be reduced. Some algae species which are created in reservoirs are poisonous and harmful to human and aquatic creatures (Gurung, 2007; Chapra, 1997). Also industrial usage of water might be restricted because many industries need high quality water.

Sharma et al. (2010) Investigated the Trophic State Index (TSI) of Mansi Ganga Lake in India. They showed that the rate of water quality degradation is high in this lake. It was oligotrophic in 2006 and changed to mesotrophic in 2008. Trophic state of a lake from oligotrophic to eutrophic is a gradual progress and it is necessary to monitor this state in a long term. However, sometimes the trophic state of a lake changes from month to month (Mahesh et al., 2014).

Reservoirs are resources of fresh water and many researches focus on water quality of this important resource. Yang et al. (2012) investigated the trophic state of 11 subtropical reservoirs in Fujian province during summer 2010. All 11 reservoirs showed symptoms of eutrophication. Results from trophic studies on lakes and reservoirs could identify the limiting nutrient which is helpful in applying managerial strategies to reduce the rate of water quality degradation.

Mahesh et al. (2014) investigated the trophic state of Dantaramakki Lake in February, March and April. The lake showed meso-trophic symptoms in February and March and eutrophic symptoms in April.

Many studies focused on eutrophication of lakes, ponds and reservoirs in Iran (Javid et al., 2014; Jalilzadeh et al., 2013). This country is located in an arid geographical region and protection of water resources is necessary to maintain fresh water.

Ecbatan reservoir is a resource of drinking water for Hamedan city and is exposed to eutrophication problem (Norouzi et al., 2011). The concentration of nutrients is considerable in this lake (Samarghandi et al., 2013).

Ecbatan Dam is a drinking reservoir located in Hamadan city, which has eutrophication potential (Norouzi et al., 2011; Taheri and Ghahghaie, 2016). In this study, the eutrophication state of Ecbatan reservoir is investigated in July, 2014 and January, 2015. Considering that summer season is critical in terms of algae growth (more temperature and light in the environment).
Previous studies show that TSI is highly dependent on air temperature and precipitation. More light and temperature is available in summer which can increase the rate of eutrophication. Also stratification is complete in Ecbatan reservoir during summer while there is a full circulation of water in winter. Any information about the response of water quality to environmental factors helps to change the withdraw rule of the reservoir and choose the proper decision to prevent severe water quality degradation. The aim of this study is to investigate and compare the trophic state of Ecbatan reservoir in dry and wet seasons as the most critical time in a year in terms of precipitation and temperature which can change the trophic state of the reservoir.

\section{Materials and Methods}

\section{The Study Area}

Hamedan is a mountainous city located in west of Iran. It is the center of Hamedan Province. The city is located in the hillside of Alvand Mountain in 1800 masl and has a cold climate. Abshine River originates from Alvand Mountain and enters to Ecbatan reservoir. Ecbatan Dam is located in south west of Hamedan on Abshine River where two branches of Yalfan and Abru join together. This Dam is located between $34^{\circ} 45^{\prime} 24^{\prime \prime} \mathrm{N}$ and $48^{\circ} 36^{\prime} 10^{\prime \prime} \mathrm{E}$. The area of the reservoir at normal level is $1.75 \mathrm{~km}^{2}$. Figure 1 shows the location of the study area and Fig. 2 shows the sampling points in July and January.

Primary structure of this dam was first built in 1963 to supply agriculture and potable water for Hamedan. The rate of erosion is high in Ecbatan watershed and a huge amount of sediment settled in the reservoir. The height of the dam was increased $25 \mathrm{~m}$ in 2008 .

15 points were determined for sampling in Ecbatan Lake. Coordinates of all points were determined using Global Positioning System (GPS). These points were selected so that cover all parts of the lake. Summer sampling was accomplished in July 2014 and winter sampling was done in January 2015.

The Characteristics of sampling points for July and January are shown in Table 1.

Sampling was accomplished in $30 \mathrm{~cm}$ of water depth. Temperature, $\mathrm{pH}$, Sechi disk, Total Phosphate (TP), Total Nitrate (TN) and chla were sampled and measured in this research.

Samples were analyzed in water and waste water laboratory of Hamedan. TP and TN were measured in laboratory using the standard method. Also the concentration of chla was determined in plant physiology laboratory of science faculty in Bu Ali Sina University, using NMM method (Huang and Cong, 2007). 


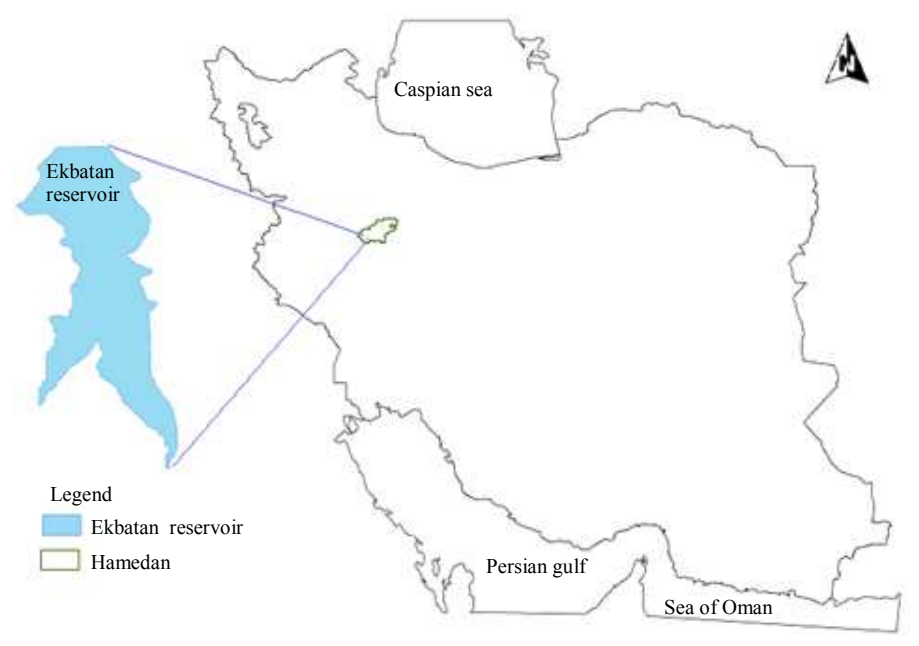

Fig. 1: Ecbatan reservoir

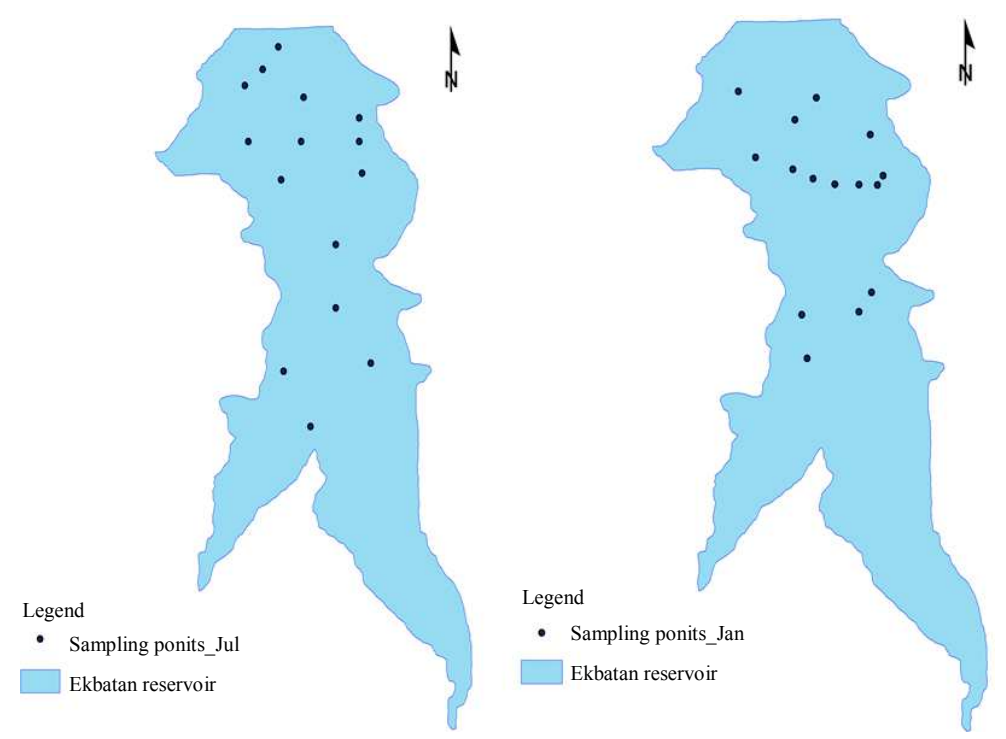

Fig. 2: Sampling points in July 2014 (a) and January 2015 (b)

Table 1: Characteristics of sampling points in January and July

\begin{tabular}{|c|c|c|c|c|c|}
\hline \multicolumn{3}{|c|}{ Characteristics of sampling points in January } & \multicolumn{3}{|c|}{ Characteristics of sampling points in July } \\
\hline Point no. & Long. & Lat. & Point no. & Long. & Lat. \\
\hline$\overline{1}$ & $48^{\circ} 35^{\prime} 54.6^{\prime \prime}$ & $34^{\circ} 45^{\prime} 15.48^{\prime \prime}$ & 1 & $48^{\circ} 36^{\prime} 4.32^{\prime \prime}$ & $34^{\circ} 45^{\prime} 15.5^{\prime \prime}$ \\
\hline 2 & $48^{\circ} 35^{\prime} 57.1^{\prime \prime}$ & $34^{\circ} 45^{\prime} 7.6^{\prime \prime}$ & 2 & $48^{\circ} 36^{\prime} 12.2^{\prime \prime}$ & $34^{\circ} 45^{\prime} 12.9^{\prime \prime}$ \\
\hline 3 & $48^{\circ} 36^{\prime} 2.1^{\prime \prime}$ & $34^{\circ} 45^{\prime} 6.1^{\prime \prime}$ & 3 & $48^{\circ} 36^{\prime} 12.2^{\prime \prime}$ & $34^{\circ} 45^{\prime} 10.1^{\prime \prime}$ \\
\hline 4 & $48^{\circ} 36^{\prime} 4.7^{\prime \prime}$ & $34^{\circ} 45^{\prime} 5.0^{\prime \prime}$ & 4 & $48^{\circ} 36^{\prime} 3.9^{\prime \prime}$ & $34^{\circ} 45^{\prime} 10.1^{\prime \prime}$ \\
\hline 5 & $48^{\circ} 36^{\prime} 7.9^{\prime \prime}$ & $34^{\circ} 45^{\prime} 4.3^{\prime \prime}$ & 5 & $48^{\circ} 35^{\prime} 56.4^{\prime \prime}$ & $34^{\circ} 45^{\prime} 10.1^{\prime \prime}$ \\
\hline 6 & $48^{\circ} 36^{\prime} 11.1^{\prime \prime}$ & $34^{\circ} 45^{\prime} 4.3^{\prime \prime}$ & 6 & $48^{\circ} 36^{\prime} 12.9^{\prime \prime}$ & $34^{\circ} 45^{\prime} 6.5^{\prime \prime}$ \\
\hline 7 & $48^{\circ} 36^{\prime} 13.7^{\prime \prime}$ & $34^{\circ} 45^{\prime} 4.3^{\prime \prime}$ & 7 & $48^{\circ} 36^{\prime} 1.1^{\prime \prime}$ & $34^{\circ} 45^{\prime} 5.4^{\prime \prime}$ \\
\hline 8 & $48^{\circ} 36^{\prime} 14.4^{\prime \prime}$ & $34^{\circ} 45^{\prime} 5.4^{\prime \prime}$ & 8 & $48^{\circ} 35^{\prime} 58.7^{\prime \prime}$ & $34^{\circ} 45^{\prime} 19.1^{\prime \prime}$ \\
\hline 9 & $48^{\circ} 36^{\prime} 12.6^{\prime \prime}$ & $34^{\circ} 45^{\prime} 10.4^{\prime \prime}$ & 9 & $48^{\circ} 35^{\prime} 55.7^{\prime \prime}$ & $34^{\circ} 45^{\prime} 17.3^{\prime \prime}$ \\
\hline 10 & $48^{\circ} 36^{\prime} 5.4^{\prime \prime}$ & $34^{\circ} 45^{\prime} 14.8^{\prime \prime}$ & 10 & $48^{\circ} 36^{\prime} 0.7^{\prime \prime}$ & $34^{\circ} 45^{\prime} 21.9^{\prime \prime}$ \\
\hline 11 & $48^{\circ} 36^{\prime} 2.5^{\prime \prime}$ & $34^{\circ} 45^{\prime} 12.2^{\prime \prime}$ & 11 & $48^{\circ} 36^{\prime} 9.0^{\prime \prime}$ & $34^{\circ} 44^{\prime} 57.5^{\prime \prime}$ \\
\hline 12 & $48^{\circ} 36^{\prime} 3.2^{\prime \prime}$ & $34^{\circ} 44^{\prime} 48.5^{\prime \prime}$ & 12 & $48^{\circ} 36^{\prime} 9.0^{\prime \prime}$ & $34^{\circ} 44^{\prime} 49.9^{\prime \prime}$ \\
\hline 13 & $48^{\circ} 36^{\prime} 3.9^{\prime \prime}$ & $34^{\circ} 44^{\prime} 43.1^{\prime \prime}$ & 13 & $48^{\circ} 36^{\prime} 14.0^{\prime \prime}$ & $34^{\circ} 44^{\prime} 43.1^{\prime \prime}$ \\
\hline 14 & $48^{\circ} 36^{\prime} 11.2^{\prime \prime}$ & $34^{\circ} 44^{\prime} 48.9^{\prime \prime}$ & 14 & $48^{\circ} 36^{\prime} 1.4^{\prime \prime}$ & $34^{\circ} 44^{\prime} 42 . "$ \\
\hline 15 & $48^{\circ} 36^{\prime} 12.9^{\prime \prime}$ & $34^{\circ} 44^{\prime} 51.4^{\prime \prime}$ & 15 & $48^{\circ} 36^{\prime} 5.4^{\prime \prime}$ & $34^{\circ} 44^{\prime} 35.1^{\prime \prime}$ \\
\hline
\end{tabular}


Table 2: Classification of eutrophication (Ebrahimpour et al., 2012)

\begin{tabular}{lll}
\hline No. & Eutrophic state & Range \\
\hline $\mathbf{1}$ & Oligotrophic & $0<$ TSI $<30$ \\
$\mathbf{2}$ & Mild Mesotrophic & $30<$ TSI $<40$ \\
$\mathbf{3}$ & Mesotrophic & $40<$ TSI $<50$ \\
$\mathbf{4}$ & Acute Mesotrophic & $50<$ TSI $<60$ \\
$\mathbf{5}$ & Eutrophic & $60<$ TSI $<70$ \\
$\mathbf{6}$ & Hypertrophic & $70<$ TSI $<80$ \\
$\mathbf{7}$ & Acute Hypertrophic & $80<$ TSI $<100$ \\
\hline
\end{tabular}

In this study Carlson trophic index (Carlson, 1997) was used to determine the eutrophication state of the lake. The value of TSI is calculated using three quality parameters such as chla, TP $\left(\mu \mathrm{g} \mathrm{L}^{-1}\right)$ and SD (m) based on Equation 1 to 3:

$$
\begin{aligned}
& T S I_{(S D)}=10\left(6-\frac{\ln S D}{\ln 2}\right) \\
& T S I_{(S P)}=10\left(6-\ln \frac{\frac{48}{T P}}{\ln 2}\right) \\
& T S I_{(C I-a)}=10\left(6-\frac{2.04-0.69 \ln (C I-a)}{\ln 2}\right)
\end{aligned}
$$

The units of chl-a and TP concentration is $\mu \mathrm{gl}-1$ and the unit of $\mathrm{SD}$ is $\mathrm{m}$ in these equations.

Total amount of TSI is the average of TSI (Chla), TSI (SD) and TSI (TP). The value of TSI varies between 1 and 100. Based on this index the trophic state of the lakes could be categorized to oligotrophic, mesotrophic, eutrophic and hypertrophic.

Also there are other classifications based on this value which categorizes a water body into seven classes (Ebrahimpour et al., 2012; Yang et al., 2012) in a more accurate classification (Table 2).

In this research chla concentration, $\mathrm{SD}$ and $\mathrm{TP}$ concentration were used to calculate the value of TSI at each individual sampling point for two seasons. The results of study are presented in results and discussion section.

\section{Results and Discussion}

After analysis of the samples, bar graphs of $\mathrm{pH}, \mathrm{SD}$, $\mathrm{TP}, \mathrm{TN}$, temperature and chla were plotted. These charts show changes in water quality parameters of Ecbatan reservoir at the sampling points both for January and July.

SD changes is presented in Fig. 3. SD has an inverse relationship with turbidity. Consequently, stations with a greater value of SD display less chla and turbidity at the measurement point. A comparison between SD values in January and July shows that this value has decreased in January. In other words the water is more turbid in January.

Variations of $\mathrm{pH}$ are shown in Fig. 4. This parameter varies between 6.2 and 7.6 at sampling points for both months. Figure 4 shows that the value of $\mathrm{pH}$ has increased in January. This is true for chla concentration as shown in Fig. 5. There is a big difference in the values of chla concentration for January and July. Figure 6 shows the variation of temperature at different sampling points.

Also Fig. 7 and 8 show the variation of TP and TN at sampling points respectively. The values of TP has increased in January at different sampling points. However TN values has decreased in some points. The ratio of N/P has declined for the majority of samples in this January (Fig. 9). This ratio has decreased mainly since water level of the reservoir has declined and the amount of TP is readily available in the reservoir in January. It is obvious that the limiting factor of eutrophication is TP in this lake.

Figure 10 shows the variations of TSI for January and July. After analysis of samples the value of TSI was determined based on three parameters of chla, TP and SD. The value of TSI for different sampling points varies between 35.7 and 50.7 in July. TSI values vary between 55.1 and 58.6 in January. Figure 9 shows this variation in different sampling points both for July and January.

Also radar graph of TSI values is shown in Fig. 11. This graph shows that 13 stations in Ecbatan reservoir are mild mesotrophic and two stations are mesotrophic (points 13 and 15) in July. Based on the average value of total TSI for the lake in July and January the state of the lake is mild mesotrophic and acute mesotrophic in July and January respectively. Although we expected more eutrophication in summer as environmental factors such as higher temperature, longer daytime and less rain increase the rate of eutrophication. Also stratification of this reservoir is completed in summer while in winter a complete circulation happens and no stratification happens in the reservoir (Weysi et al., 2013).

The results show that the quality of water in reservoir has changed from mild mesotrophic in July to acute mesotrophic in January. On the contrary found that the quality of water in winter is more convenient (TSI $=46$, mesotrophic) than summer (TSI $=53.7$, acute mesotrophic). 


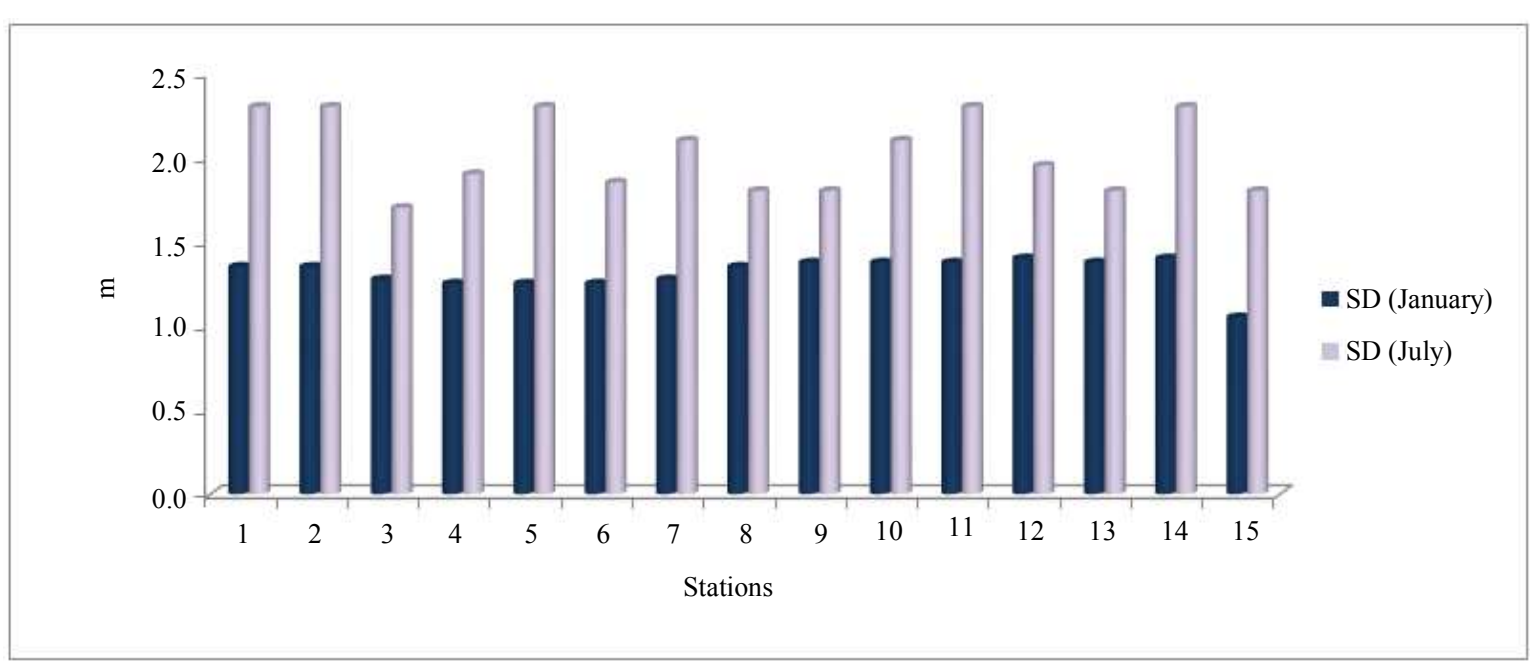

Fig. 3: SD variation at sampling points for January and July

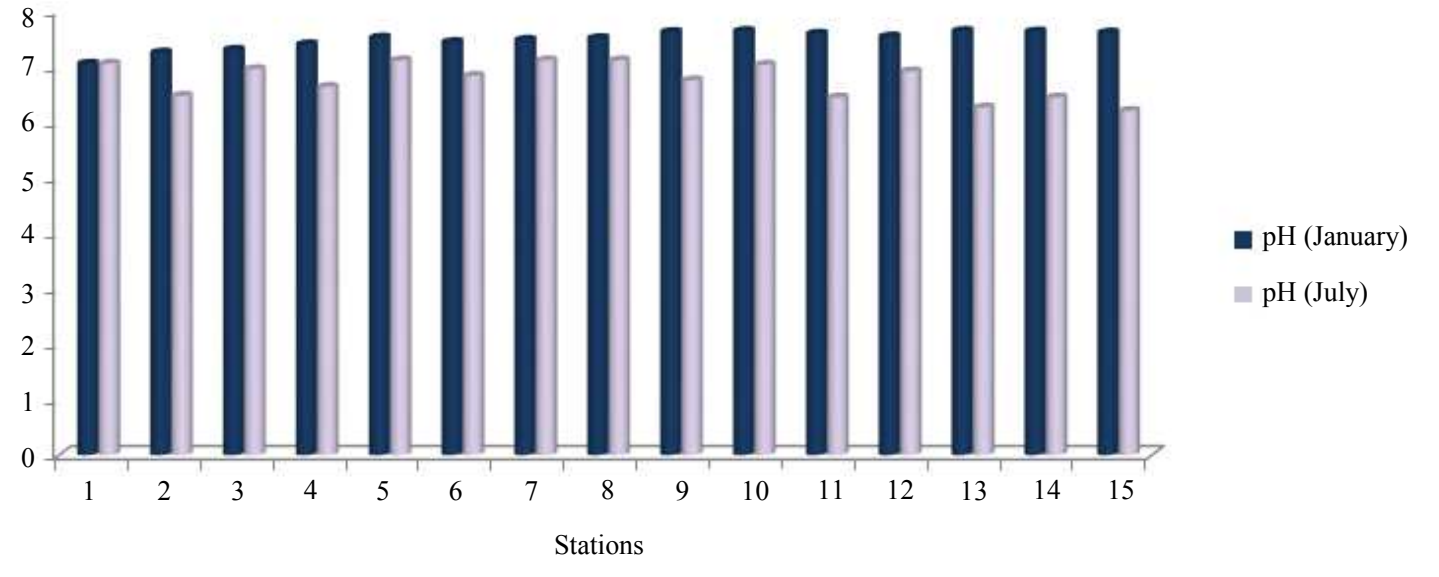

Fig. 4: pH variation at sampling points for January and July

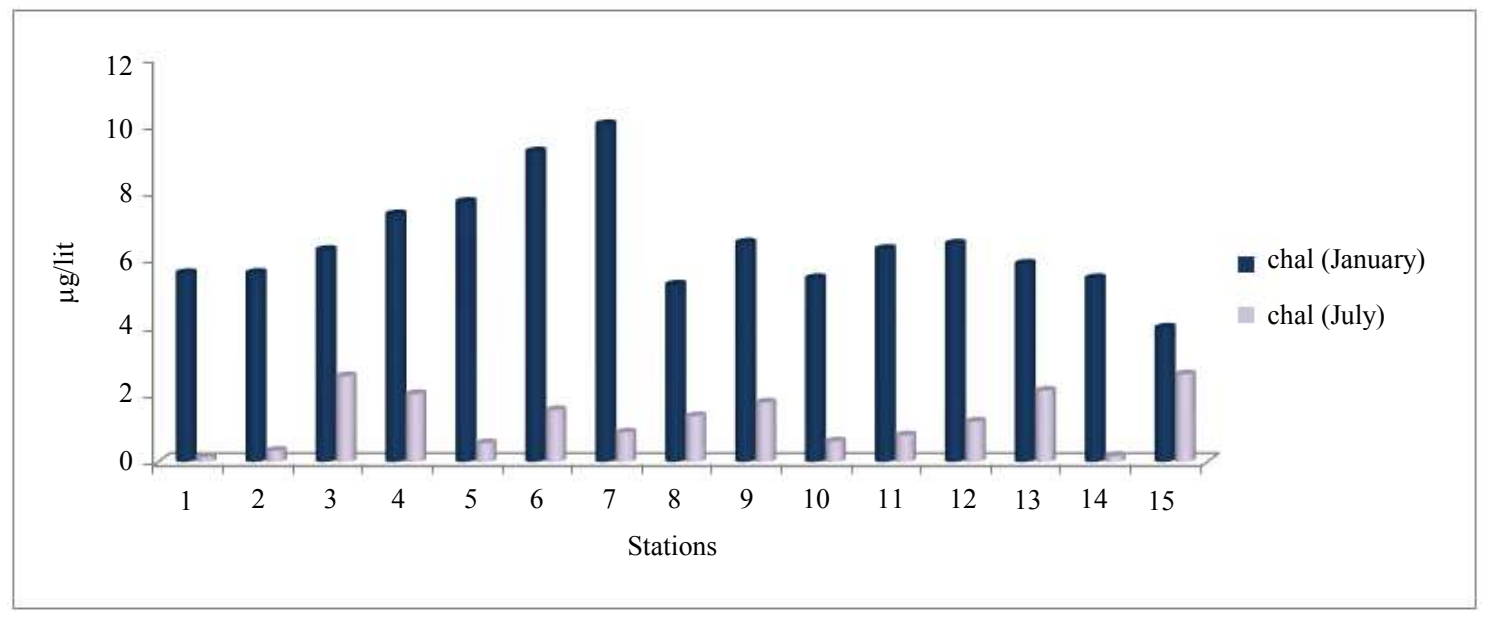

Fig. 5: Chla variation at sampling points for January and July 


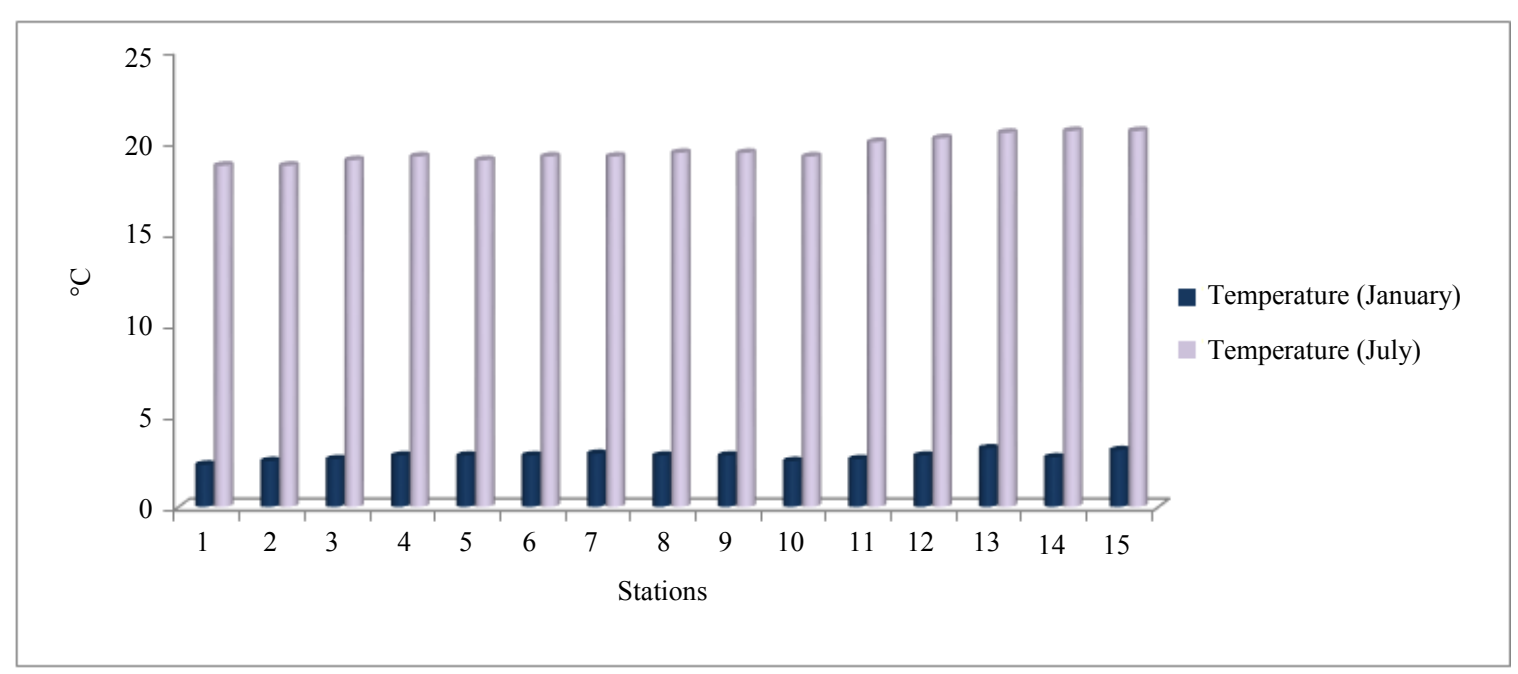

Fig. 6: Temperature variations at sampling points for January and July

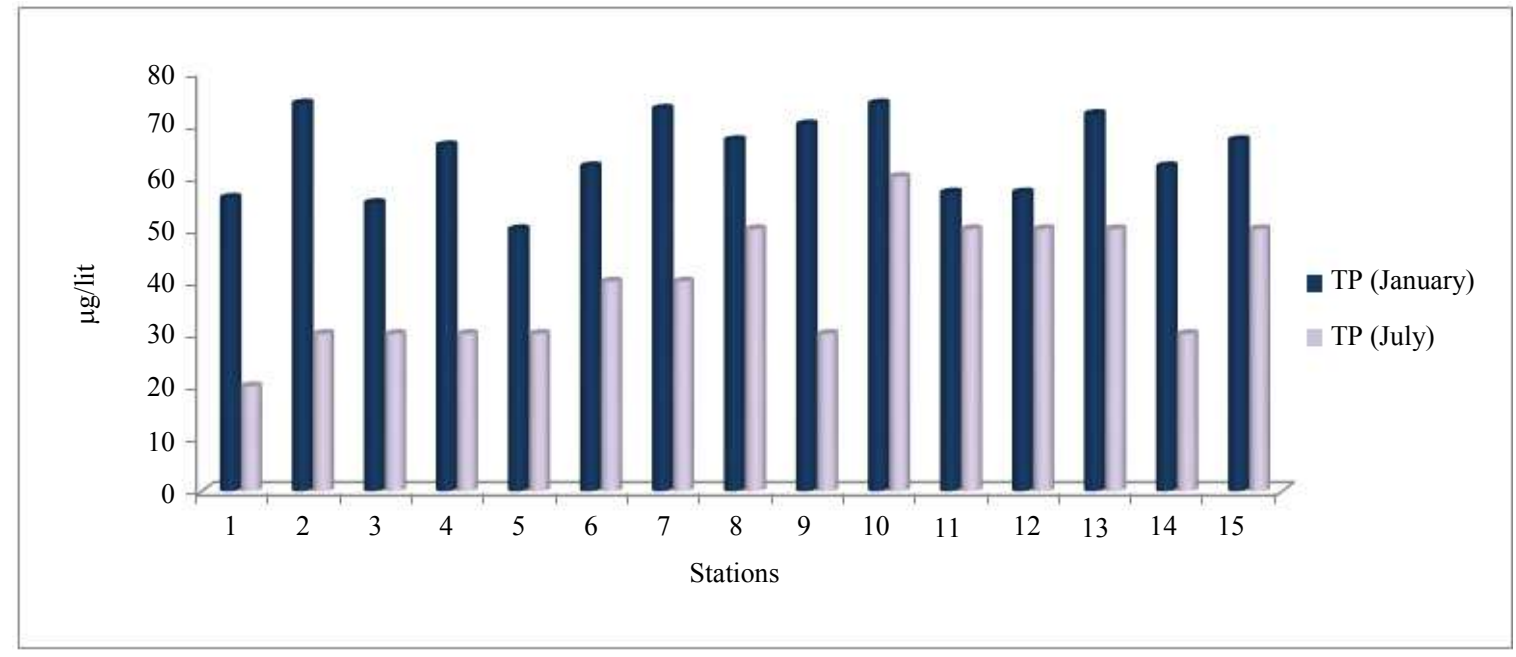

Fig. 7: TP variation at sampling points for January and July

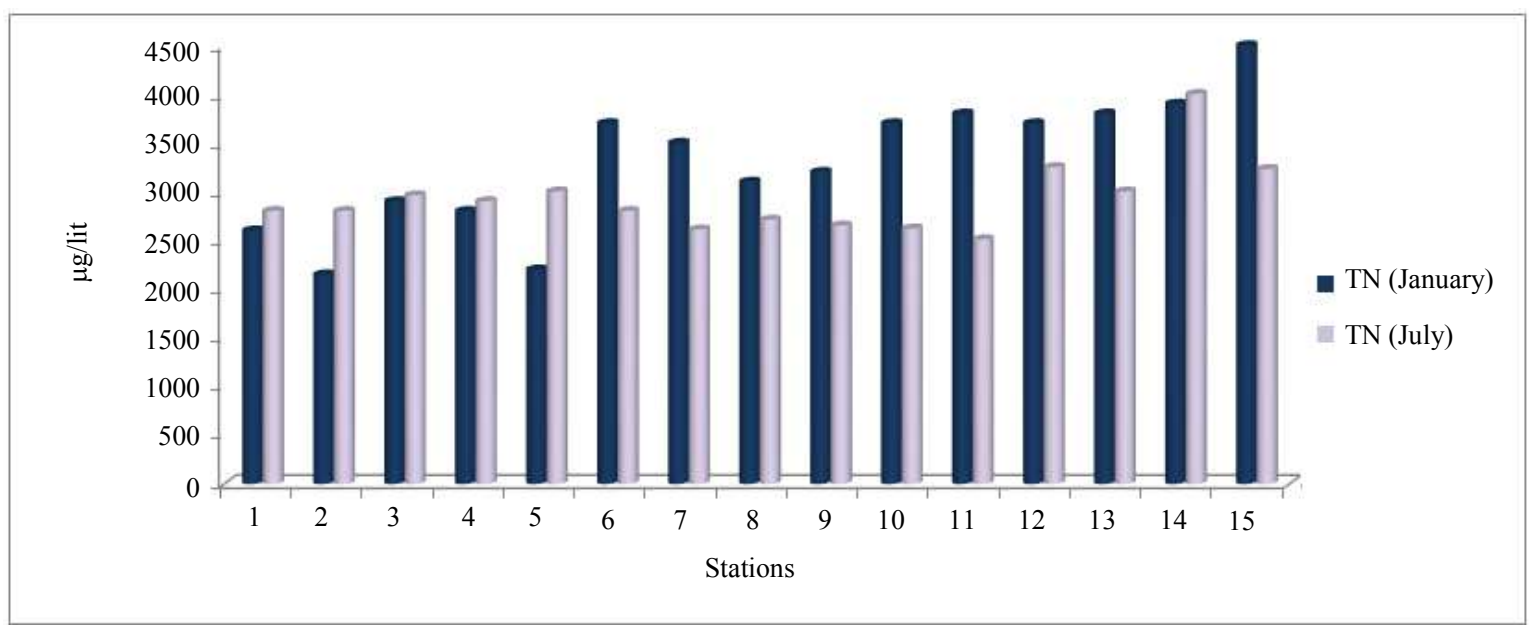

Fig. 8: TN variation at sampling points for January and July 


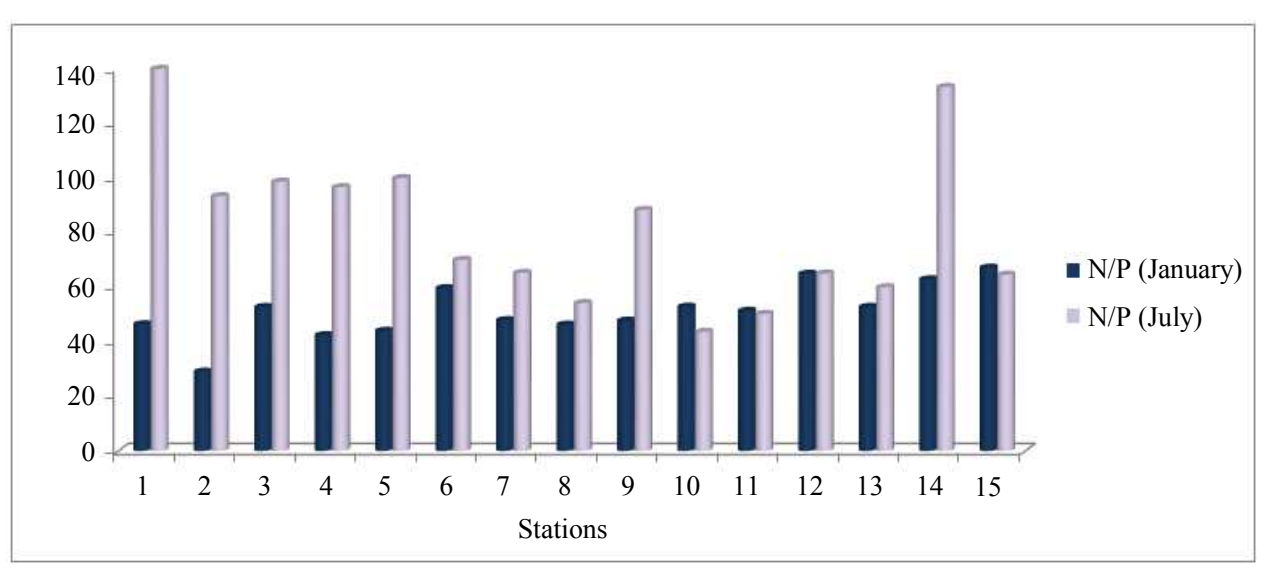

Fig. 9: Variation of N/P ration at sampling points for January and July

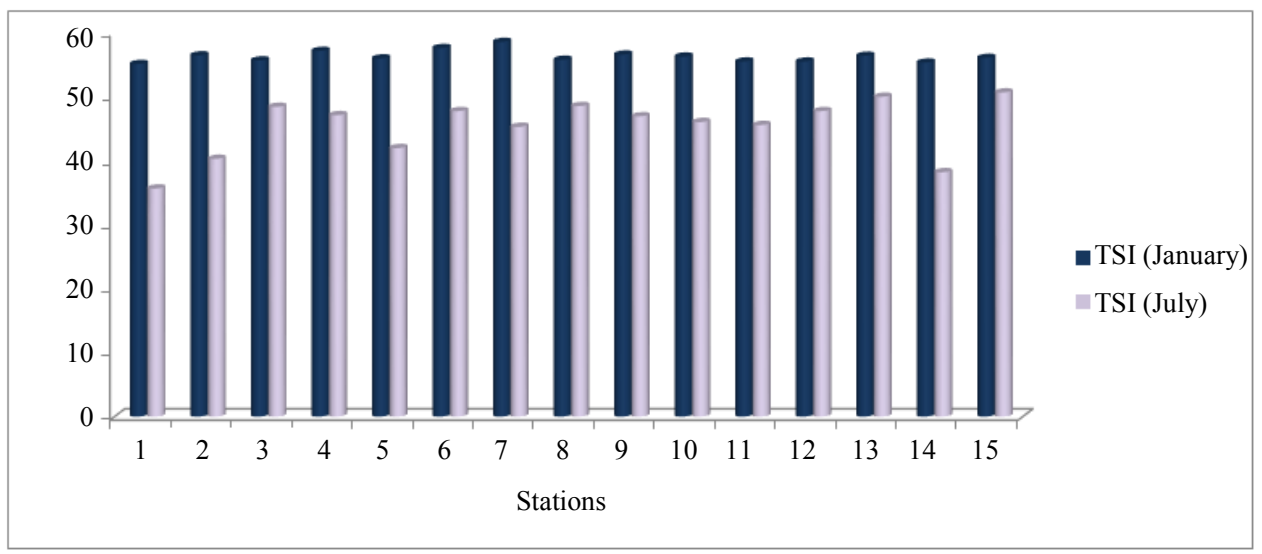

Fig. 10: Carlson index at sampling points for July and January

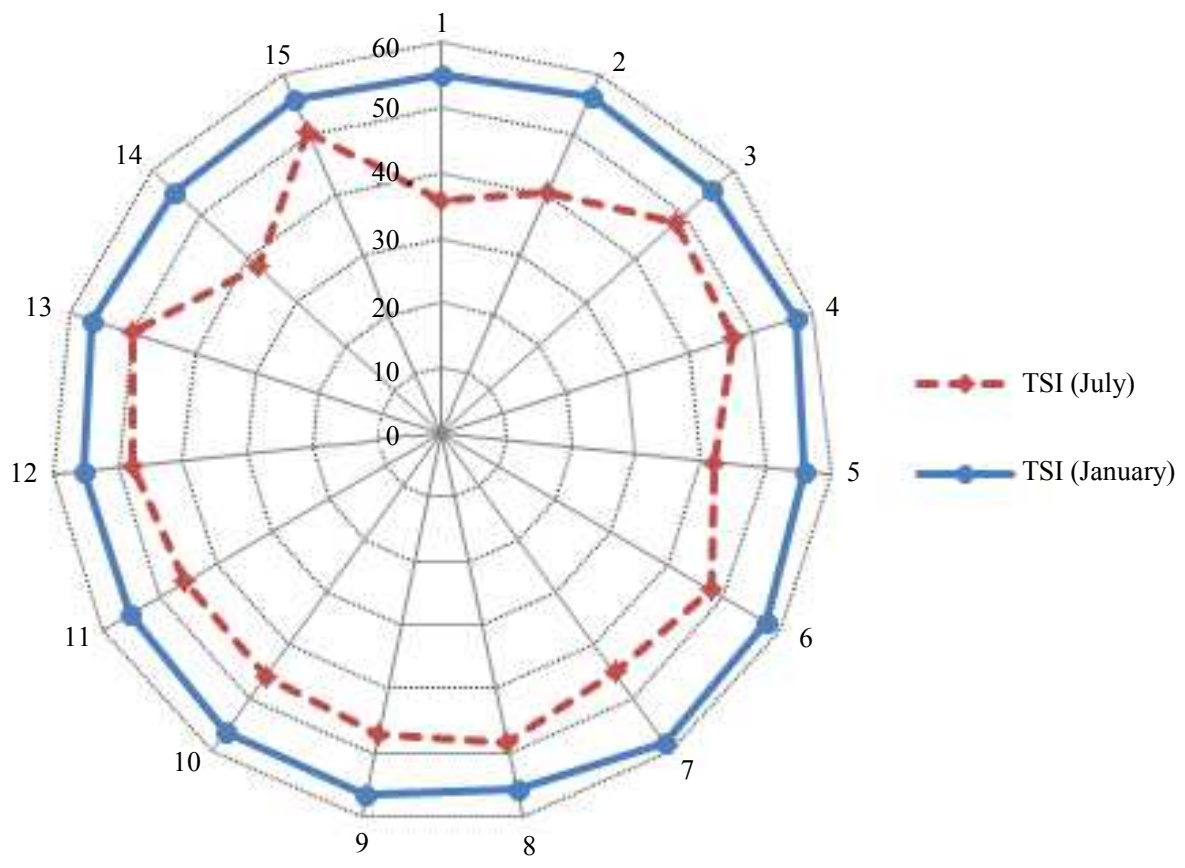

Fig. 11: Radar Graph of TSI values at sampling points in July and January 
Therefore we referred to water volume of reservoir in summer and winter for both 2015 and 2010. The volume of water in reservoir was about 30 and 16.4 MCM in July, 2010 and January, 2011 respectively. The reservoir was in a normal year in 2010. Also the volume of water in the reservoir was 17.7 and 5.3 MCM in July, 2014 and January, 2015 which is a hydrological dry year.

Ecbatan reservoir receives a significant amount of sediment from upstream watershed and transparency of this water body is affected by suspended materials. Therefore Equation 1 might cause misleading results in determining the trophic class of reservoir. Cigagna et al. (2016) neglected the Equation 1 because the case study of their research was a reservoir affected by turbidity of suspended materials. Also Lorenzen (1980) proved that this equation doesn't show the net effect of algae and other suspended materials could influence this value.We modified the results by removing Eq. 1 and used Carlson's classification to determine the trophic state of the reservoir. Table 3 shows TSI values based on chla, TP and SD.
Besides if two indices show the same trophic class for the environment, the degree of limitation is normal. When TSI (chla) ranks the environment in a class higher than TSI (TP), the degree of limitation is low since the situation is convenient for phytoplankton productivity. On the contrary if the value of TSI (TP) ranks the environment in a higher class of eutrophication, the degree of limitation is high (Lamparelli, 2004).

In this study TSI (TP) value is higher than TSI (chla) both for dry and wet seasons indicating that the degree of limitation is high. Table 4 shows the range of TP, chla and TSI of Ecbatan reservoir for both seasons.

Also min, max and the average values of TSI for dry and wet seasons with/without considering TSI (SD) are shown in Table 5.

Trophic state of the reservoir varies between oligotrophic and mesotrophic for 15 stations in dry season neglecting TSI (SD) while it varies between mild mesotrophic and mesotrophic considering TSI (SD). Also for wet season no difference was observed for trophic state of the reservoir between the results of considering TSI (SD) and neglecting this value.

Table 3: Carlson classification of trophic state (Carlson, 1977)

\begin{tabular}{lrcc}
\hline TSI & SD $(\mathrm{m})$ & Surface TP $(\mu \mathrm{g} /$ lit $)$ & Surface chla $(\mu \mathrm{g} /$ lit $)$ \\
\hline 0 & 64.000 & 0.75 & 0.04 \\
10 & 32.000 & 1.50 & 0.12 \\
20 & 16.000 & 3.00 & 0.34 \\
30 & 8.000 & 6.00 & 0.94 \\
40 & 4.000 & 12.00 & 2.60 \\
50 & 2.000 & 24.00 & 6.40 \\
60 & 1.000 & 48.00 & 20.00 \\
70 & 0.500 & 96.00 & 56.00 \\
80 & 0.250 & 192.00 & 154.00 \\
90 & 0.120 & 384.00 & 427.00 \\
100 & 0.062 & 768.00 & 1183.00 \\
\hline
\end{tabular}

Table 4: The range of TP, chla and TSI for Ecbatan reservoir in January and July

\begin{tabular}{|c|c|c|c|c|}
\hline & \multicolumn{2}{|l|}{ Wet season } & \multicolumn{2}{|l|}{ Dry season } \\
\hline & $\mathrm{TP}(\mu \mathrm{g} /$ lit $)$ & chla $(\mu \mathrm{g} / \mathrm{lit})$ & $\mathrm{TP}(\mu \mathrm{g} /$ lit $)$ & chla $(\mu \mathrm{g} / \mathrm{lit})$ \\
\hline Min & 50 & 4 & 20 & 0.1 \\
\hline Max & 74 & 10 & 60 & 2.6 \\
\hline TSI & $60-70$ & $40-60$ & $40-70$ & $10-50$ \\
\hline
\end{tabular}

Table 5: TSI mean value for dry and wet seasons with/ without considering TSI (SD) TSI

$\begin{array}{llll} & \text { With SD } & \text { Min } & \mathbf{5 5 . 1} \\ \text { Wet Season } & & \text { Max } & 58.6 \\ & & \text { Average } & 56.3 \\ & & \text { Min } & 54.5 \\ & & \text { Max } & 59.6 \\ \text { Without SD } & \text { Average } & 56.4 \\ \text { Wry Season } & & \text { Min } & 35.7 \\ & & \text { Max } & 50.7 \\ & & \text { Average } & 45.4 \\ & \text { Without SD } & \text { Min } & 29.5 \\ & & \text { Max } & 50.3 \\ & & \text { Average } & 43.1\end{array}$


Different factors such as nutrients entrance, the volume of water in the reservoir, precipitation and the amount of release from the reservoir affect the trophic state of a water body. The results of this study are in agreement with (Prasad and Siddaraju, 2012) that the trophic state of a reservoir might change from year to year and it can show significant changes from season to season. Also in some regions precipitation and water increase in a reservoir might deteriorate the state of eutrophication. Since more nutrients are carried to water bodies through surface streams (Cigagna et al., 2016).

\section{Conclusion}

Ecbatan reservoir is a resource of drinking and agriculture water for Hamedan city. This study investigated the trophic state of Ecbatan Dam Lake using Carlson index. In this study, 15 stations in the reservoir were identified and sampling from these points was carried out in July, 2014 and January, 2015.

The results of this study showed that Ecbatan reservoir has a serious problem of eutrophication. Trophic state of a lake from oligo-trophic to eutrophic or hypertrophic is a gradual progress. Consequently it is necessary to choose a period for monitoring the quality of reservoirs so that it covers the normal, wet and dry periods because the trophic state of a reservoir is a function of different environmental conditions and operational rules. Especially in a situation like Ecbatan reservoir where a high amount of sediment occupies a considerable volume of the lake and water level decline can increase the rate of eutrophication due to readily available $\mathrm{P}$ in the environment.

Due to the fact that drinking water supply in Hamadan is one of the objectives of Ecbatan reservoir, it is necessary to prevent water quality decline in reservoir using managerial strategies in the upstream of the basin.

\section{Acknowledgement}

We thanks all participants and authors that cooperate in the presents study.

\section{Author's Contributions}

Maryam Ghashghaie and Mohammad Reza Serajian Maralan: Write manuscript and analyzed data. Kaveh Ostad-Ali-Askari: Write manuscript and revise it.

Saeid Eslamian, Vijay P. Singh and Nicolas R. Dalezios: Design the study and revise manuscript.

\section{Ethics}

This study was approved by Water Resources Engineering Department, Faculty of Agriculture, Bu-Ali Sina University, Hamedan, 6517833131, Iran.

\section{References}

Arheimer, B., G. Torstensson and H.B. Wittgren, 2004. Landscape planning to reduce coastal eutrophication: Agricultural practices and constructed wetlands. Landscape Urban Plann., 67: 205-215. DOI: 10.1016/S0169-2046(03)00040-9

Camargo, J.A., A. Alonso and M. de la Puente, 2005. Eutrophication downstream from small reservoirs in mountain rivers of central Spain. Water Res., 39: 3376-3384. DOI: 10.1016/j.watres.2005.05.048

Carlson, R.E., 1977. A trophic state index for lakes1. Limnol. Oceanogr., 22: 361-369.

DOI: $10.4319 / 10.1977 .22 .2 .0361$

Chapra, S.C., 1997. Surface Water-Quality Modeling. 1st Edn., Waveland Press, Mc Graw-Hill, New York, ISBN-10: 1478608307, pp: 844.

Cigagna, C., D.M. Bonotto, A.F.M. Camargo and J.R. Sturaro, 2016. Trophic State Index (TSI) and physico-chemical characteristics of a shallow reservoir in southeast Brazil. Environ. Earth Sci., 75: 102. DOI: 10.1007/s12665-015-4951-0

Domagalski, J., C. Lin, Y. Luo, J. Kang and S. Wang et al., 2007. Eutrophication study at the panjiakoudaheiting reservoir system, northern Hebei Province, people's Republic of China: Chlorophyll-a model and sources of phosphorus and nitrogen. Agric. Water Manage., 94: 43-53. DOI: 10.1016/j.agwat.2007.08.002

Ebrahimpour, S., H. Mohammadzade, A. Naderi and A. Azarpeykan, 2012. Evaluation of lakes eutrophication using GIS (case study: Zaribar marshy lake). Proceedings of 16th Congress of Iran Geology Association, (IGA' 12), Shiraz University, Shiraz, Iran.

Gurung, R.P., 2007. Modelling of Eutrophication in Roxo Reservoir, Alentejo, Portugal: A System Dynamic Based Approach. 1st Edu., ITC, Enschede, pp: 100 .

Huang, T.L. and H.B. Cong, 2007. A new method for determination of chlorophylls in freshwater algae. Environ. Monit. Assess. 129: 1-7. DOI: $10.1007 / \mathrm{s} 10661-006-9419-\mathrm{y}$

Jalilzadeh, E., M. Salimi and P. Roozbehnia, 2014. Detection and determination of chlorophylls $a$ and $b$ in karaj, taleghan and latian reservoirs by High Performance Liquid Chromatography (HPLC/UVVIS). J. Water Wastewater, 4: 21-26.

Javid, A.H., S.A. Mirbagheri and A. Karimian, 2014. Assessing dez dam reservoir water quality by application of WQI and TSI indices. Iranian J. Health Environ., 7: 133-142. 
Kurz, I., C. Coxon, H. Tunney and D. Ryan, 2005. Effects of grassland management practices and environmental conditions on nutrient concentrations in overland flow. J. Hydrol., 304: 35-50. DOI: $10.1016 /$ j.jhydrol.2004.07.022

Lamparelli, M.C., 2004. Trophic level in water bodies of Sao Paulo: Evaluation of measurement methods. PhD Thesis, USP-Sao Paulo University, Sao Paulo.

Li, X., Y. Xu, G. Zhao, C. Shi and Z. Wang et al., 2015. Assessing threshold values for eutrophication management using bayesian method in yuqiao reservoir, North China. Environ. Monit. Assess., 187: 195-195. DOI: 10.1007/s10661-015-4399-4.

Lorenzen, M.W., 1980. Use of chlorophyll-Secchi disk relationships. Limnol. Oceanogr., 25: 371-372. DOI: 10.4319/10.1980.25.2.0371

Mahesh, S., H. Srikantha, S.M. Kumar and S. Vathsala, 2014. Eutrophication assessment for the dantaramakki lake of chikmagalur city using GIS technique. Int. J. Chem. Tech. Res., 6: 440-449.

Norouzi, J., A. Jahani, H. Jelokhani and A. Ghasemi, 2011. Quality evaluation and assessment of ecbatan dam reservoir. Proceedings of the International Water and Wastewater Congress, (WWC' 11), Tehran, Iran.

Prasad, A.G.D. and Siddaraju, 2012. Carlson's trophic state index for the assessment of trophic status of two lakes in Mandya district. Adv. Applied Sci. Res., 3: 2992-2996.

Samarghandi, M.R., K. Weysi, E.A. Mehrizi, P. Kaseb and E. Danai, 2013. Evaluation of water quality in hamadan akbatan reservoir by NSFWQI index. J. North Khorasan Uni. Med. Sci., 5: 63-69.

DOI: 10.29252 jnkums.5.1.63
Sharma, M.P., A. Kumar and S. Rajvanshi, 2010. Assessment of trophic state of lakes: A case of mansi ganga lake in India. Hydro Nepal: J. Water, Energy Environ., 6: 65-72. DOI: $10.3126 /$ hn.v6i0.4198

Smith, D.R., B.E. Haggard, E.A. Warnemuende and C. Huang, 2005. Sediment phosphorus dynamics for three tile fed drainage ditches in Northeast Indiana. Agric. Water Manage., 71: 19-32. DOI: $10.1016 /$ j.agwat.2004.07.006

Smith, V.H., 2003. Eutrophication of freshwater and coastal marine ecosystems a global problem. Environ. Sci. Pollut. Res. Int., 10: 126-39. DOI: $10.1065 /$ espr2002.12.142

Taheri, T. and A.M. Ghashghaie, 2016. Determining the eutrophication state of ekbatan dam lake using carlson index. Iranian J. Irrigat. Water Eng., 6: 92-102.

Weysi, K., M.R. Samarghandi, M.T. Samadi, M. Safaee and H. Nourmoradi et al., 2013. Monitoring of the undesirable phenomenon of thermal stratification in reservoir dam of ecbatan, hamadan. J. Health Syst. Res., 9: 1005-1013.

Yang, J., X. Yu, L. Liu, W. Zhang and P. Guo, 2012. Algae community and trophic state of subtropical reservoirs in southeast Fujian, China. Environ. Sci. Pollut. Res., 19: 1432-1442. DOI: $10.1007 / \mathrm{s} 11356-011-0683-1$

Zhang, J., S.M. Liu, J.L. Ren, Y. Wu and G.L. Zhang, 2007. Nutrient gradients from the eutrophic Changjiang (Yangtze River) estuary to the oligotrophic kuroshio waters and re-evaluation of budgets for the East China sea shelf. Progress Oceanogr., 74: 449-478. DOI: 10.1016/j.pocean.2007.04.019 